\title{
Characterization of Structural Composition and Diversity of Vegetation in the Kpashimi Forest Reserve, Niger State, Nigeria
}

\author{
Abdullahi Jibrin $^{1} \&$ Idris A. Jaiyeoba ${ }^{1}$ \\ ${ }^{1}$ Department of Geography, Ahmadu Bello University, Zaria, Nigeria \\ Correspondence: Abdullahi Jibrin, Department of Geography, Ahmadu Bello University, Zaria, P.M.B. 1069, \\ Nigeria. Tel: 234-803-697-8420. E-mail: abdullahi717@hotmail.com
}

Received: March 17, 2013 Accepted: July 17, 2013 Online Published: July 22, 2013

doi:10.5539/jgg.v5n3p75 URL: http://dx.doi.org/10.5539/jgg.v5n3p75

\begin{abstract}
Structural attributes and floristic composition of vegetation communities was investigated in the Kpashimi Forest Reserve, Niger State, Nigeria. The aim of the study was to describe the floristic composition and structure of the plant communities found in the study area. Biometric field inventory method; involving morphometric measurements, enumeration and application of allometric equations was employed for data collection. Vegetation variables including tree density, species diversity, tree girth, basal area, tree height, crown cover, shrub cover, and grass cover were measured within forty-eight sampling plots of 0.4096 hectares; distributed over the six vegetation physiographic units found in the area including riparian forest, savannah woodland, degraded forest, scrubland, grassland, and bare surface. For data analysis, the mean and coefficient of variation were determined from the data collected for each of the six vegetation physiographic units. The result showed that the Riparian forest is characterised by mean values of girth $\left(1.16\right.$ metre), basal area $\left(26.9 \mathrm{~m}^{2}\right.$ ha- $\left.{ }^{1}\right)$ tree height (26.6 metre) and crown cover (68\%). Savannah woodland recorded density of tree stand $\left(0.0129 / \mathrm{m}^{2}\right)$ and diversity (13.75 Simpson's diversity index), while Grassland and Bare surface classes are characterised by mean values of grass cover $(89.9 \%$ and $51.1 \%$ respectively). Scrubland is characterised by mean value of shrub cover (64.8\%); but with comparatively low trunk diameter, crown cover, tree height and tree density. The study area is thus characterised by a mixture of plant communities that vary in composition, diversity, heterogeneity, structure and complexity. This study presents acquired baseline information on the landscape vegetation structure and composition which could be useful for characterizing a typical savannah vegetation structure and composition. The data obtained could also provide a reference scenario against which future assessments could be compared; in order to understand the dynamics of vegetation communities.
\end{abstract}

Keywords: biocomplexity, description, composition, structure, diversity, woodland savannah

\section{Introduction}

The savanna biome is characterized by heterogeneity in the physiognomy and spatial structure of the vegetation (Ratter et al., 1997; Augustine, 2003; Bucini \& Hanan, 2007; Levick et al., 2009) where a mosaic with high and low-cover patches is created by the varied proportion of woody plants interspersed in a grass matrix (Sarmiento, 1984). Vegetation structure generally considers the composition of plant community in terms of specific morphological characteristics while composition is the floristic assemblage of plant species that characterize the vegetation (Martin, 1996). The coexistence and spatially heterogeneous distribution of different life form layers of woody and herbaceous vegetation (Frost, 1996; Sankaran et al., 2005) may be responsible for low mapping accuracies of savanna land cover classes, as shown in several comparative assessment studies (Giri et al., 2005; Hansen \& Reed, 2000). Thus, the properties of the mix of woody and herbaceous vegetation can be very important in understanding the complex information on the relation between land cover and the properties of each class or physiographic unit (Privette et al., 2004).

Knowledge on structural characteristics of vegetation is highly demanded both globally and locally. On the global scale, more detailed and standardized data on biomass and vegetation structure of vegetation units are needed (Brown \& Gaston, 1996; FAO, 2001) in order to parameterise global vegetation maps (Loveland et al., 1999). On the local scale, information on structural characteristics of vegetation as well as standardized inventories of these properties are important for detailed structural descriptions of both the tree and the herb 
layer with respect to the stratified vegetation types, and secondly, to compare the vegetation types in terms of structural parameters (Hahn, 1996; Devineau et al., 1997).

The theoritical framework of the study is hinged on the concept of 'biocomplexity' defined as "properties emerging from the interplay of behavioural, biological, chemical, physical, and social interactions that affect, sustain, or are modified by living organisms, including humans" (Michener et al., 2001). Studies and theories abound on the coexistence of trees and grasses in savannas, such as McNaughton (1983), Scholes and Walker (1993), and Venter et al. (2003). Sanford and Isichei (1986) elaborated a classification for West African savannas based on physiognomic and structural characteristics giving detailed values for stem density and girth distribution of the tree layer. On local and regional scale, some studies used floristic data for classification (e.g. Sinsin, 1993; Hahn, 1996; Devineau et al., 1997; Sokpon et al., 2001).

In contrast to abundant studies and theories on the coexistence of trees and grasses in savannas, studies describing species composition and structural properties are sparse for West African savanna systems (Schmidt, 1973; Sinsin, 1993). Such knowledge, is however required in order to expand the understanding of ecosystem processes (Hahn, 1996), to relate vegetation maps to ecological properties (Devineau, 2001), and as a basis for modelling approaches (Brown \& Gaston, 1996; FAO, 2001). Furthermore, the dearth of data quantifying tree physiognomies restricts our understanding of the regional and global impacts of ecological changes in savannas (Scholes et al., 2002). In this context the research question is stated thus: Which floristic composition and vegetation structure occur in different vegetation types found in the study area? Therefore, the objectives of this study includes: to describe the current floristic composition and structure of the plant communities that occur in the study area and secondly, to compare the vegetation types in terms of structural parameters.

\section{Materials and Methods}

\subsection{Study Area}

Kpashimi Forest Reserve is located on latitude $8^{\circ} 38^{\prime}$ to $8^{\circ} 52^{\prime}$ North and $6^{\circ} 34^{\prime}$ to $6^{\circ} 48^{\prime}$ East covering approximately 213.101 kilometres square (Figure 1). The study area lies within the tropical hinterland (tropical rainy climate with dry season) climatic belt of Nigeria; characterised by alternating wet and dry season coded as 'Aw' by Koppen's classification. The mean annual rainfall is about $1,300 \mathrm{~mm}$ with mean annual temperature of about $28^{\circ} \mathrm{C}(\mathrm{Ojo}, 1977)$. The geology of the study area is made up of cretaceous sedimentary rocks underlain by the Precambrian basement complex rocks (FORMECU, 1994). The topography is gently undulating, sloping generally towards different directions in different locations. Soils in the study area based on the CCTA (Commission de Cooperation Technique en Afrique) classification system belong to ferruginous tropical soils. In some depressional areas, and valley bottom positions hydromorphic soils are found; while those around the inselbergs and other residual hills, and at the bed of rivers, are weakly developed (Areola, 1978; Jaiyeoba \& Essoka, 2006). The study area lies within the southern Guinea savannah zone classified as woodland savannah vegetation with the understory dominated by annual grasses (Keay, 1953; Jaiyeoba \& Essoka, 2006).

\subsection{Data Collection}

\subsubsection{Determination of Sample Plot Number, Size and Location}

Stratified random sampling was employed in order to capture the variability of land cover (Rosenfield, 1982). The strata were based on the supervised classification of NIGERIASAT-1 satellite imagery, and subsequently, different classes of land cover classes of the study area were obtained. Selection of samples was done by visual display and analysis of the NIGERIASAT-1 classified image of 2007, using Arc GIS 9.2. On display, in the Arc GIS environment, the vegetation cover classes were identified. Eight pixels were randomly selected from each of the vegetation classes on the imagery; and their coordinates recorded (See Appendix A); totalling 48 sampling units. In order to determine the size (area) of sampling plots, Justice and Townshend (1981) Model was applied. The model estimates the size of any sample quadrat as a function of the pixel size and the expected geometric accuracy of the images.

$$
\mathrm{A}=[\mathrm{PD}(1+2 \mathrm{PG})]^{2}
$$

Where: $\mathrm{A}=$ Area to be sampled, $\mathrm{PD}=$ Ground diameter of a pixel, $\mathrm{PG}=$ Geometric accuracy of the image.

Thus, NIGERIASAT-1 with pixels that are 32 meter in diameter on the ground and are located to an accuracy of \pm 0.5 pixels, the sample plot size used for the study was justified to be 0.4096 hectares or 64 meter by 64 meter.

Locating of sampling points was achieved with the aid of a GPS receiver (Garmin GPS MAP 76). Selected points were determined to the nearest minuit. The actual field work started by the laying down of squared sample plots of 64 meter by 64 meter on the ground using compass and tape measure. At the centre of the point, a 64 
metre tape was laid. Demarcation of the sample plot boundaries was established by measuring 32 meters each side of the centre transect; marked by ranging poles, and aligned with the aid of prismatic compass. Once a sample point location was prepared, the GPS was used to establish the coordinates. Latitude and Longitude (WGS 32-UTM) of each survey point was recorded on the data sheet. From these plots, trees are numbered, counted and identified by species. This was followed by the measurements of tree height and girth (for all woody stems longer than $3 \mathrm{~m}$ high at 1.35 breast height. Next, was the laying of transect line (64 meter in lenght) across the quadrat plot from north to south; in order to measure the magnitude of crown cover, shrub cover, and grass cover.

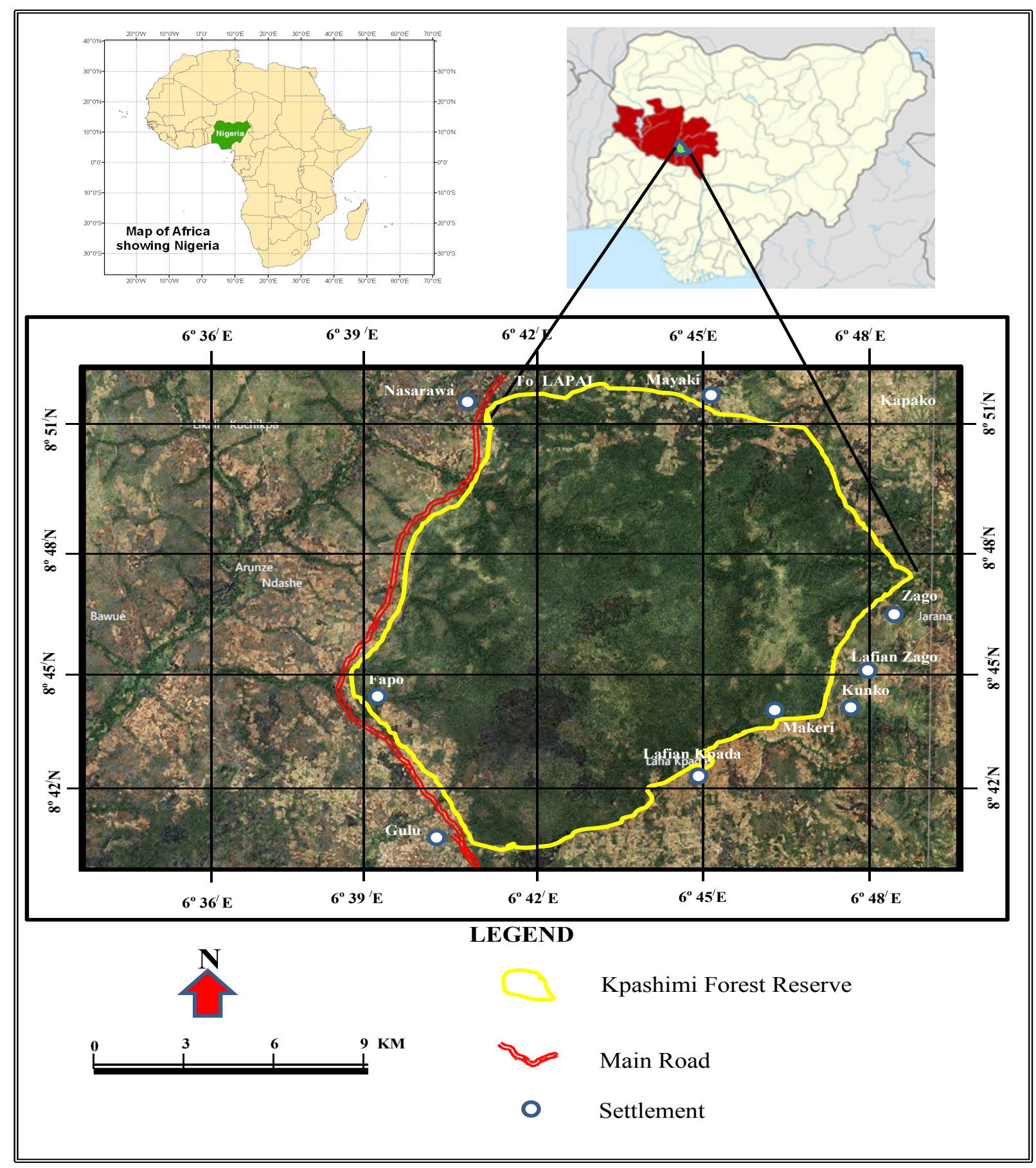

Figure 1. Map showing the location of study area

Source: Niger State Forest Management Unit. 


\subsubsection{Measurement of Vegetation Parameters}

Tree Species height measurement: Considered in the measurement of tree height was the vertical length between the ground (lowest part of the tree stem) and the tallest living part for all trees measured in meter. Clinometers was used to determine the angle of elevation, while the distance from the foot of the tree to the observer was recorded. The height of the observer at eye level was noted and the height of the tree was subsequently determined by using the formula: (Gareth, 1991)

$$
\mathrm{X}=\mathrm{Y} * \tan \AA+\mathrm{Z}
$$

Where: $\mathrm{X}=$ tree height, $\mathrm{y}=$ distance from the tree to the observer, $\AA=$ angle of elevation, $\mathrm{z}=$ height of the observer at eye level.

Tree Girth (Trunk Diameter at Breast Height): This involved measurement of individual trees circumference at 1.35 meters breast height, measured in meters. Measurement was done with the aid of a measuring tape (Eyre et al., 2006).

Tree Species Density and Diversity: This involved determining the degree of concentration and frequency of occurrence of tree species in a particular area. This is important for estimating biomass density per unit area, and adaptation of individual species to specific areas. This was determined by enumerating and recording the total number of respective trees species found within each of the sample plot (Eyre et al., 2006).

$$
\text { Density }=\frac{\text { Total number of species in quadrat }}{\text { Size of quadrat }}
$$

In order to investigate the extent of plant diversity within the forest reserve, diversity indices were calculated for physiographic units using the inverse of Simpson's (1949) diversity index. Species diversity is a measure of heterogeneity of a site taking into consideration the number and the density of individual species. The Simpson's diversity index is expressed as:

$$
I=\frac{N\{N-1\}}{\sum\left\{n_{i}\left(n_{i}-1\right)\right\}}
$$

Where: $I=$ Simpson's diversity index, $N=$ Total number of species enumerated, $n_{i}=$ Number of individuals of $i$ th species enumerated.

The inverse of the original Simpson index was used so as to remove the ambiguity in the original Simpson index, hence the higher the value of $I$, the greater the heterogeneity.

Crown cover: This involved the estimation of canopy cover of a tree or group of trees in each quadrat, measured in percentage. Based on line transect method, trees whose projected canopy intersect the 64 meter transect, observed between 11:00 am and 1:00 pm; when the sun was at its zenith were recorded. The total length of the projected canopy was divided by the total length of the tape to give an estimate of crown cover (Eyre et al., 2006).

$$
\text { Crown cover }=\frac{\text { Total estimated crown cover }}{\text { Total length } \text { of transect }} \times 100
$$

Basal Area: This involved determining the cross sectional area of the tree trunk at 1.35 meters above the ground, measured in square metre. This parameter was determined based on the formula by Wratten and Fry (1980).

$$
\text { Basal Area }=\frac{C^{2}}{4 \pi}
$$

Where: $C=$ girth size (diameter at breast height), $\pi=22 / 7=3.14$.

Shrub cover: Estimation of the shrub cover was done by transect method. The vertical projection of the shrub canopy over the $64 \mathrm{~m}$ transect was measured and recorded. The total length of the projected canopy was divided by the total length of the tape to give an estimate of percent canopy cover for the shrub layer (Eyre et al., 2006).

$$
\text { Shrub cover }=\frac{\text { Total Estimated shrub cover }}{\text { Total length of transect }} \times 100
$$


Grass cover: Transect method was used in the estimation of grass cover. The vertical projection of the grass cover over the $64 \mathrm{~m}$ transect was measured and recorded. The total length of the projected grass cover was divided by the total length of the tape to give an estimate of percent for the grass layer (Eyre et al., 2006).

$$
\text { Grass cover }=\frac{\text { Total Estimated grass cover }}{\text { Total length of transect }} \times 100
$$

\subsubsection{Data Analysis}

The data collated was analysed first by arithmetic mean $(\overline{\mathbf{x}})$ in order to derive the standard average value for distinctive vegetation cover of the study area.

$$
\overline{\mathrm{x}}=\frac{1}{n} \cdot \sum_{i=1}^{n} x_{i}
$$

In order to allow for meaningful comparison between magnitudes of variations in mean values of the data collected, the coefficient of variation (CV) was employed. It represents the ratio of the standard deviation to the mean and often expressed as a percentage. The coefficient of variation is a helpful statistical method in comparing the degree of variation from one data series to the other, although the means may be considerably different from each other.

$$
C V=\frac{S D}{\overline{\mathbf{x}}} \times 100
$$

Where: CV: coefficient of variation, SD: Standard deviation, $\bar{x}$ : Mean.

\section{Results}

The mean values of data collected on measured structural attributes and composition of the woody vegetation, including tree density, species diversity, tree girth, basal area, Tree height, crown cover, shrub cover, and grass

\begin{tabular}{|c|c|c|c|c|c|c|c|c|c|}
\hline $\begin{array}{l}\text { PHYSIOGRAI } \\
\text { UNITS }\end{array}$ & PHIC & $\begin{array}{l}\text { Tree } \\
\text { Density } \\
\left(\mathrm{m}^{2}\right) \\
\end{array}$ & $\begin{array}{l}\text { Species } \\
\text { Diversity }\end{array}$ & $\begin{array}{l}\text { Tree } \\
\text { Girth } \\
\text { (metre) }\end{array}$ & $\begin{array}{l}\text { Basal Area } \\
\left(\mathrm{m}^{2} \mathrm{ha}^{-1}\right)\end{array}$ & $\begin{array}{l}\text { Tree } \\
\text { Height } \\
\text { (metre) }\end{array}$ & $\begin{array}{l}\text { Crown cover } \\
\text { (Percentage) }\end{array}$ & $\begin{array}{l}\text { Shrub cover } \\
\text { (Percentage) }\end{array}$ & $\begin{array}{l}\text { Grass cover } \\
\text { (Percentage) }\end{array}$ \\
\hline \multirow{2}{*}{$\begin{array}{l}\text { BARE } \\
\text { SURFACE }\end{array}$} & $\overline{\mathbf{x}}$ & 0.0025 & 3.68 & 0.54 & 6.3 & 11.3 & 4.75 & 20.03 & 51.11 \\
\hline & $\mathrm{CV}(\%)$ & 36 & 20.4 & 35.2 & 65.4 & 27.4 & 125.7 & 36.1 & 13.9 \\
\hline \multirow{2}{*}{ GRASSLAND } & $\overline{\mathbf{x}}$ & 0.0041 & 5.38 & 0.43 & 4.6 & 17.6 & 10.30 & 28.9 & 89.86 \\
\hline & CV $(\%)$ & 24.4 & 22.1 & 41.9 & 73.7 & 17.6 & 48.2 & 38.5 & 7.0 \\
\hline \multirow{2}{*}{ SCRUBLAND } & $\overline{\mathbf{x}}$ & 0.0063 & 7.13 & 0.71 & 11.2 & 17.2 & 19.14 & 64.81 & 27.84 \\
\hline & CV (\%) & 30.2 & 29.5 & 38.0 & 87.0 & 14.2 & 46.2 & 25.5 & 54.2 \\
\hline \multirow{2}{*}{$\begin{array}{l}\text { DEGRADED } \\
\text { FOREST }\end{array}$} & $\overline{\mathbf{x}}$ & 0.0074 & 9.38 & 0.81 & 13.7 & 17.5 & 36.65 & 35.34 & 32.64 \\
\hline & $\mathrm{CV}(\%)$ & 31.1 & 17.1 & 23.5 & 46.4 & 12.1 & 24.5 & 45.8 & 20.3 \\
\hline \multirow{2}{*}{$\begin{array}{l}\text { SAVANNAH } \\
\text { WOODLAND }\end{array}$} & $\overline{\mathbf{x}}$ & 0.0129 & 13.75 & 1.03 & 20.7 & 19.0 & 57.40 & 35.95 & 25.81 \\
\hline & $\mathrm{CV}(\%)$ & 22.5 & 15.9 & 14.6 & 28.2 & 7.6 & 16.2 & 35.5 & 28.4 \\
\hline \multirow{2}{*}{$\begin{array}{l}\text { RIPARIAN } \\
\text { FOREST }\end{array}$} & $\overline{\mathbf{x}}$ & 0.0103 & 7.88 & 1.16 & 26.9 & 26.6 & 67.73 & 11.09 & 18.83 \\
\hline & CV $(\%)$ & 17.5 & 19.6 & 17.2 & 35.5 & 13.4 & 13.5 & 22.4 & 24.5 \\
\hline
\end{tabular}
cover are presented in Table 1 below.

Table 1. Mean values of vegetation structural attributes and floristic composition

Source: Fieldwork, 2008.

Note: $\overline{\mathbf{x}}=$ mean, $\mathbf{C V}=$ Coefficient of variation.

A total of 1,415 trees were enumerated and measured during the field inventory. From the summary in Table 1, the Savannah woodland records the highest number of trees per quadrat (about 53 trees per 0.4 hectares) and correspondingly recorded the highest tree density of 0.0129 per square meter. It also indicated comparatively low coefficient of variability $(23.5 \%)$. Conversely, bare surface records the lowest number of trees; about 10 trees per 0.4 hectares and similarly has the lowest tree density $(0.0025)$ per square meter, though with highest coefficient of variability (31.6\%). The values for Riparian forest are 42 trees per quadrat and density of 0.0103 per square meter. Grassland, Scrubland and degraded forest recorded intermediate values. Figure 2 illustrates the 
comparison of tree density among the vegetation communities.

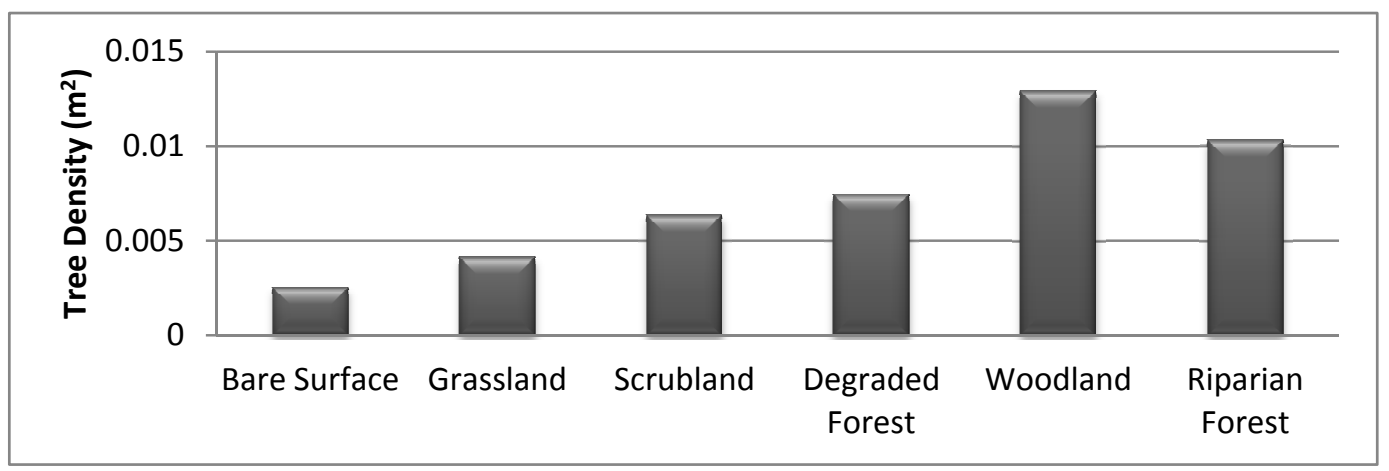

Figure 2. Comparison of tree density

In terms of tree species heterogeneity and frequency of occurrence, Table 1 indicates that Savannah woodland recorded highest number of species richness with an average of 13.75 per quadrat. It was followed by Degraded forest (9.38 per quadrat). While Riparian forest and Scrubland recorded 7.8 and 7.3 respectvely, Bare surface and Grassland areas recorded lower species diversity having 3.63 and 5.38 respectively. Therefore, with Savannah woodland having the highest mean value and lowest coefficient of variability, it suggests that Savannah woodland is most diverse in terms of species variety. Figure 3 illustrates the comparison of tree Species Diversity among the vegetation communities.

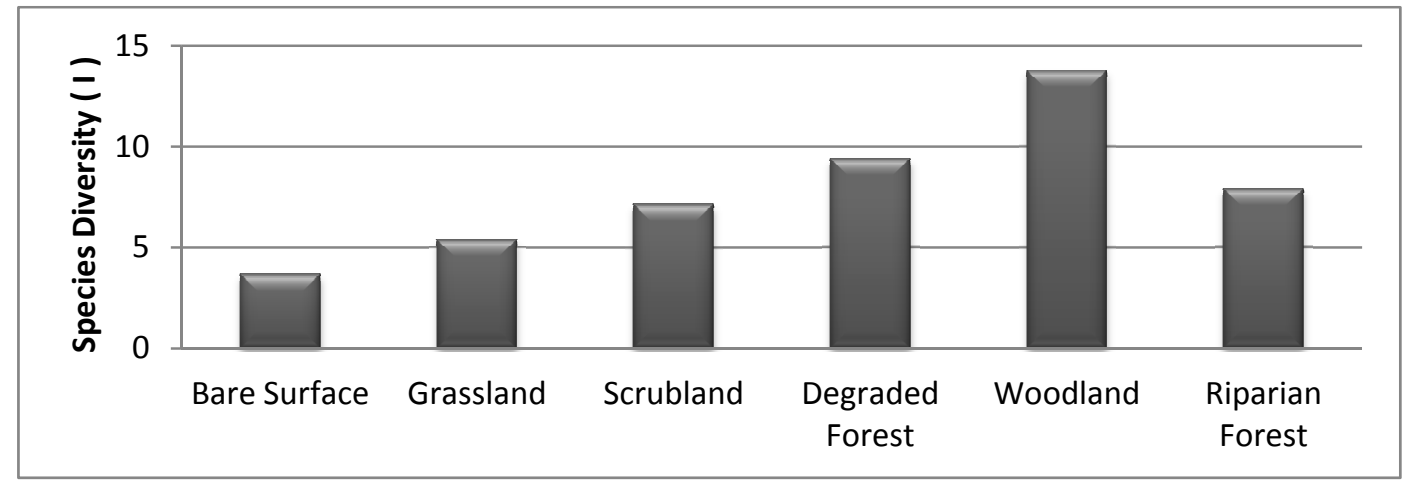

Figure 3. Comparison of species diversity

Table 1 shows that Riparian forest has the highest mean value for trunk diameter (1.16 meter), followed by Savannah woodland (1.03), Degraded forest (0.71), Bare surface (0.54) and Grassland recorded the lowest (0.43) though with high coefficient of variability $(41.9 \%)$. Figure 4 illustrates the comparison of tree girth among the vegetation communities.

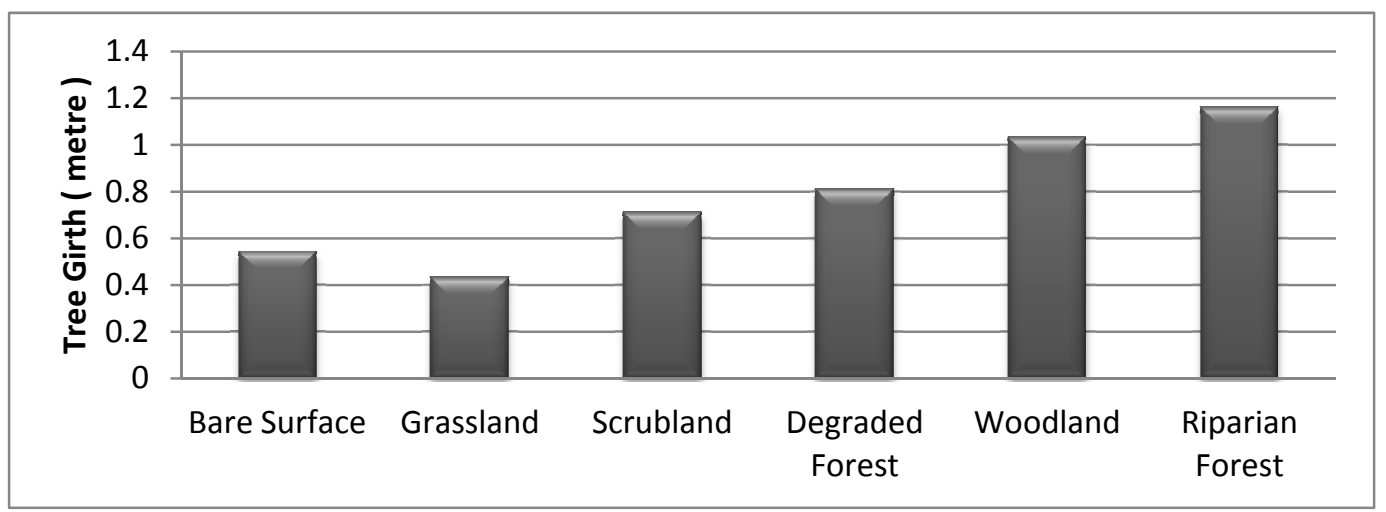

Figure 4. Comparison of tree girth 
Data on tree basal area of the various vegetation communities exhibit similar pattern with that of tree girth. Considering the summarised data in Table 1, vegetation communities with high mean girth size values have proportionately high values for basal area. Riparian forest and Savannah woodland with fewer evidence of anthropogenic disturbance recorded comparatively higher values of $20.7 \mathrm{~m}^{2} \mathrm{ha}^{-1}$ and $26.9 \mathrm{~m}^{2} \mathrm{ha}^{-1}$ respectively; whereas Degraded forest, Scrubland, Grassland, and Bare surface with ample evidences of anthropogenic disturbance, recorded lower values $13.7 \mathrm{~m}^{2} \mathrm{ha}^{-1}, 11.2 \mathrm{~m}^{2} \mathrm{ha}^{-1}, 4.6 \mathrm{~m}^{2} \mathrm{ha}^{-1}$ and $6.3 \mathrm{~m}^{2} \mathrm{ha}^{-1}$ respectively. Figure 5 illustrates the comparison of tree basal area among the vegetation communities.

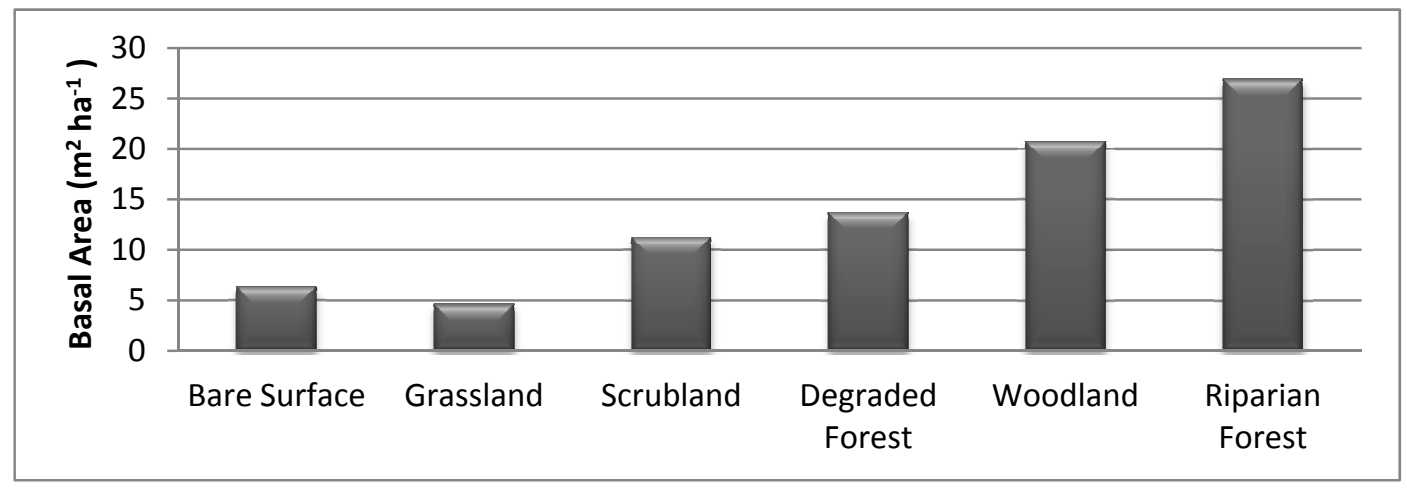

Figure 5. Comparison of basal area

Summary of data on tree height measurement over the six vegetation communities (Table 1) reveals that Riparian forest has the highest mean tree height of (26.6 meter), followed by Savannah woodland (19 meters). Values for the Grassland, Degraded forest and Scrubland are intermediate and approximately 17 meters. Bare surface has the lowest (11.3 meters). Regarding the variability of tree heights within the respective vegetation communities, Bare surface indicated the highest coefficient of variability $(27.4 \%)$, followed by Grassland $(17.6 \%)$, Scubland (14.2\%), Riparian forest (13.4\%), Degraded forest $(12.1 \%)$ and Savannah woodland has the least $(7.6 \%)$. Figure 6 illustrates the comparison of tree height among the vegetation communities.

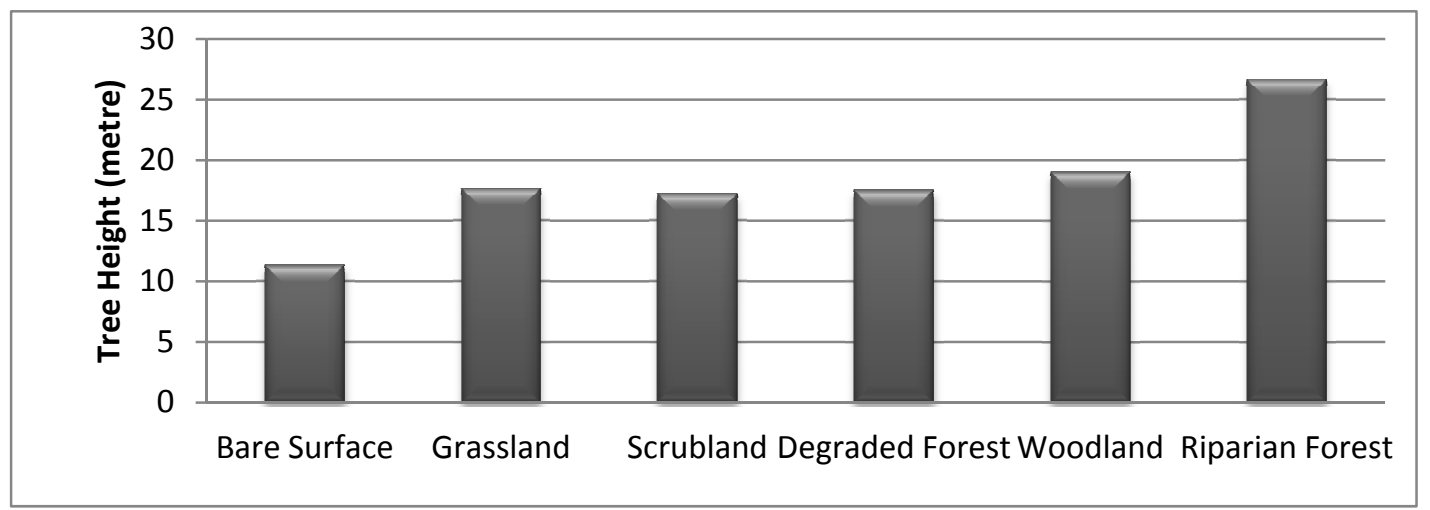

Figure 6. Comparison of tree height

Results on tree crown cover, with reference to Table 1 shows that Riparian forest recorded the highest mean value of $67.7 \%$, followed by Savannah woodland (57.4\%), Degraded forest (36.65\%), Scrubland (19.1\%) and Bare surface (4.8\%). It is also evident that vegetation communities with lower values of crown cover shows higher values of coefficient of variability such as Bare surface (125.7\%), Grassland (48.2\%), Scrubland (46.2\%), Degraded forest (24.5\%), Savannah woodland (16.2\%) and Riparian forest $(13.5 \%)$. Figure 7 illustrates the comparison of crown cover among the vegetation communities. 


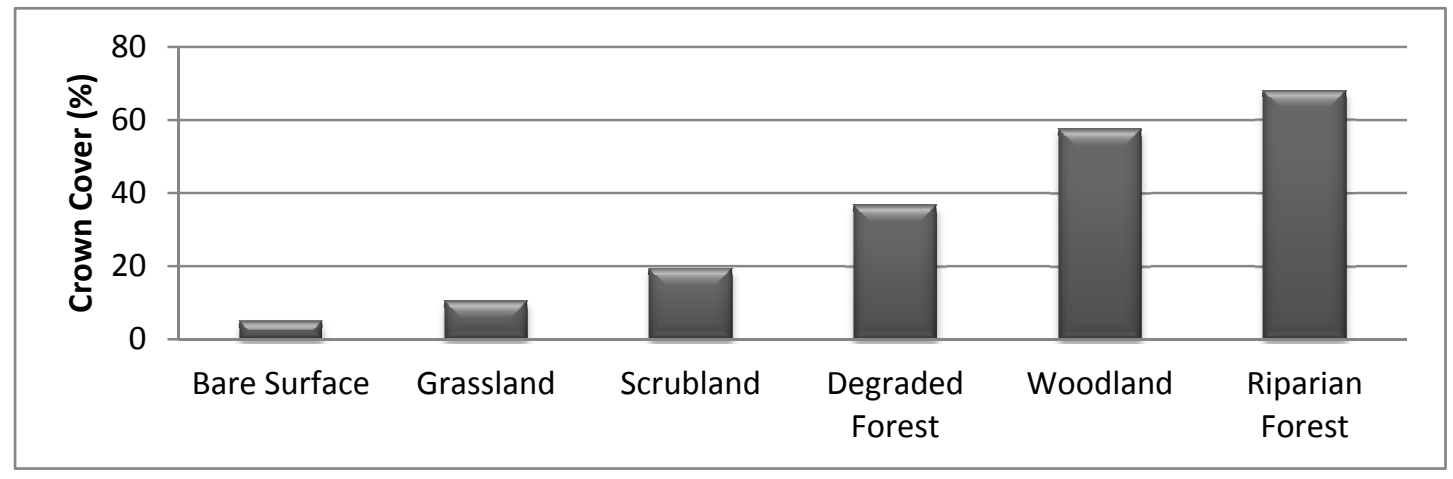

Figure 7. Comparison of crown cover

With regards to shrub cover, it is observable from Table 1 that Scrubland recorded the highest mean value of $64.8 \%$, followed by Savannah woodland (35.95\%), Degraded forest (35.34\%), Grassland (28.92\%), Bare surface $(20.03 \%)$ and Riparian forest $(11.09 \%)$. Coefficient of variability within each of the vegetation communities reveal that Degraded forest recorded the highest (45.8\%), followed by grassland (38.5\%), Bare surface (36.1\%), Savannah woodland (3.5\%), Scrubland (25.5\%), and Riparian forest (22.4\%) Figure 8 illustrates the comparison of shrub cover among the vegetation communities.

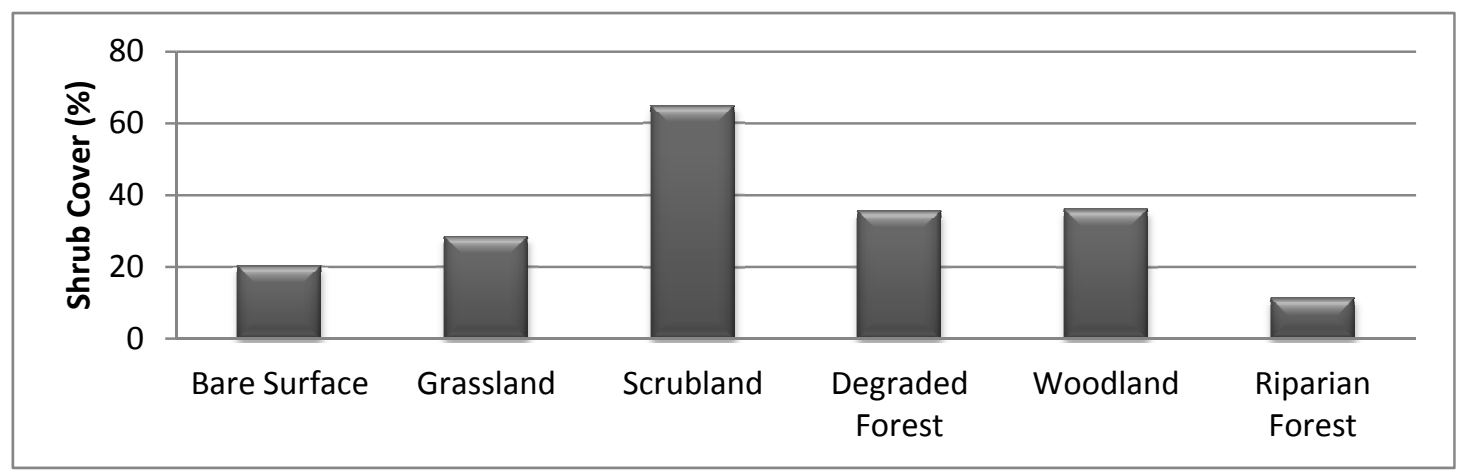

Figure 8. Comparison of shrub cover

With reference to Table 1, Grass cover measured indicated that Grassland recorded the highest mean value (89.86\%), followed by Bare surface (51.11\%), Degraded forest $(32.64 \%)$, Scrubland $(27.84 \%)$, Savannah woodland $(25.81 \%)$, and Riparian forest $(18.83 \%)$. Considering variability within the vegetation communities, Scrubland shows the highest value (54.2\%), followed by Savannah woodland (28.4\%), Riparian forest (24.5\%), Degraded forest (20.3\%), Bare surface (13.9\%), and Grassland (7.0\%). Figure 9 illustrates the comparison of grass cover among the vegetation communities.

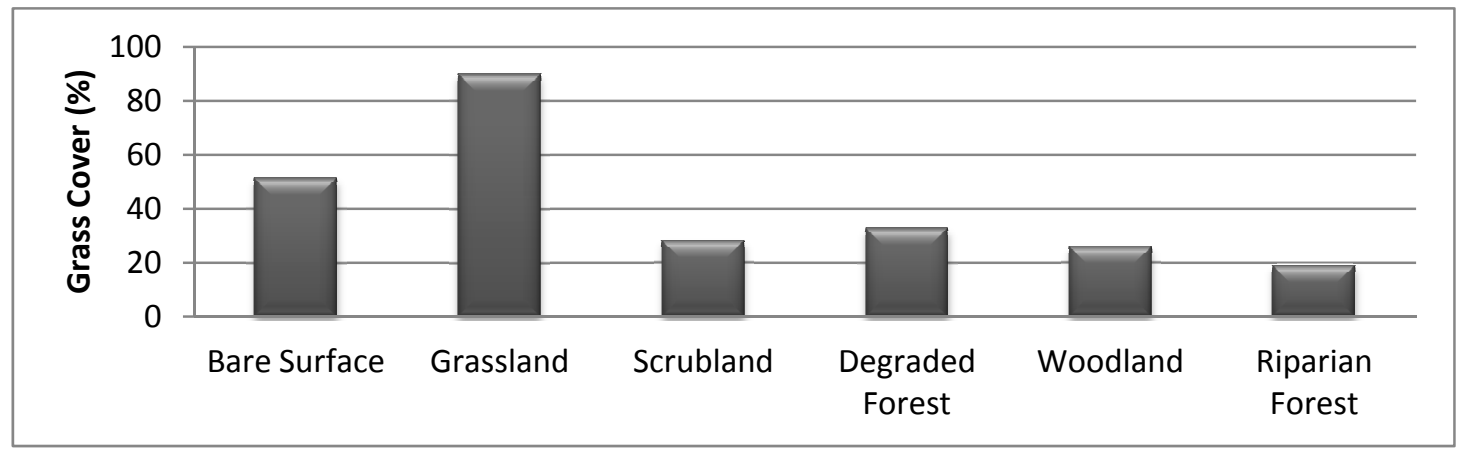

Figure 9. Comparison of grass cover 
Analysis of data on vegetation physiognomic characteristics and composition of the study area provides a clear structural attributes of the vegetation communities found in the study area. Therefore the distinctive vegetation physiographic units in the study area can be characterised as follows.

Savannah Woodland: occur either as continous or discrete entity throughout the reserve. As indicated in Table 1, it is characterised by average tree height of 19 meters; tree density $0.0129 / \mathrm{m}^{2}$; tree girth 1.03 metres; basal area $20.7\left(\mathrm{~m}^{2} \mathrm{ha}^{-1}\right)$ and crown cover of about $57 \%$, and composed of tree species such as Parkia bigloboza, Ceiba pentandra, Tamarindus indica, Daniellia oliveri, Adansonia digitata and Mangifera indica. Others are Vitex doniana, Vitaleria paradoxa, Borassus aethiopum, Afzelia africana, Acacia albida, Khaya senegalenesis, Ficus sycomorus, Pterocarpus erinaceus. Grass species may include Panicum kerstingii, Rhynchelytrum repens, Setaria pallide-fusca, Aristida.

Riparian Forest: On narrow strips bordering streams and rivers, most especially in the northern and southern parts of the reserve occurs the riparian forests. With reference to Table 1, it is characterized by average tree height of 27 meter; tree density $0.0103 / \mathrm{m}^{2}$; tree girth 1.16 metres; basal area $26.9\left(\mathrm{~m}^{2} \mathrm{ha}^{-1}\right)$ and crown cover of $68 \%$. Common tree species found include Raphia sudanica, Khaya senegalensis, Syzigium guineense, Vitex doniana, Anthocleista vogelii, Sapium ellipticum, Phoenix reclinata and Albizia zygia. The shrubs and climbers layer is made up of such species as Landolphia spp., Napoleona imperialis,Olax spp., Paullinia pinnata, Smilax kraussiana and Culcasia scandens. The herb layer may contain Oplismenus hirtellus, Megastachya mucronata, Piper capense and Anchomanes difformis.

Degraded Forest: These are areas covered by scattered trees, separated by other low lying ground cover vegetation. Table 1 indicates that it is characterized by average tree height of 17.5 meters; tree density 0.0074 / $\mathrm{m}^{2}$; tree girth 0.81 metres; basal area $13.7\left(\mathrm{~m}^{2} \mathrm{ha}^{-1}\right)$, shrub cover $35 \%$ and crown cover of $37 \%$. The vegetation community occurs in patches all over the reserve, however it is more pronounced at the perimeter of the forest reserve. Tree species found are similar to those of the savannah woodland though with lower species diversity and density.

Scrubland or Shrub Savannah: The vegetation community consists typically of shrubby coppice and sucker regeneration from stumps and rootstocks that have not yet been eliminated by cultivation. With reference to Table 1, average tree height is about 17 meters; tree density $0.0063 / \mathrm{m}^{2}$; tree girth 0.71 metres; basal area 11.2 $\left(\mathrm{m}^{2} \mathrm{ha}^{-1}\right)$; Shrub cover $65 \%$ and crown cover of $19 \%$. It occurs as patches mostly close to the perimeter of the reserve. Common species includes remnants of the savannah woodland. Pennisetum polystachyon and $P$. pedicellatum grasses are common in the early stages of newly fallowed land, but typically perennial Andropogoneae are found.

Grassland: These are areas dominated by grassy and herbaceous vegetation. The few isolated trees found may form crown cover of $10 \%$; Shrub cover $28.29 \%$; grass cover $90 \%$; average tree height of 18 meter; tree density $0.0041 / \mathrm{m}^{2}$; tree girth 0.43 metres; and basal area $4.6\left(\mathrm{~m}^{2} \mathrm{ha}^{-1}\right)$ as presented in Table 1 . It is composed of various combination of species including Echinochloa pyramidalis, Phragmites mauritianus, Saccharum spontaneum, Oryza barthii and Vetiveria nigritana. Widely scattered species of low tree such as Mitragyna inermis, Syzigium guineense and Terminalia glaucescens are also found. Typically, low and creeping grasses, such as Paspalum commersonii, Sacciolepis spp., Brachiaria jubata, Setaria sphacelata and Panicum repens, are found and mostly predominates at the edges of the forest reserve.

Bare Surface: Areas with scanty or no vegetation cover including rock outcrops, farmlands and low growing grasses form a distinct vegetation community characterized by economic trees with average height of about 11.3 meters, tree density $0.0025 / \mathrm{m}^{2}$; tree girth 0.54 metres; basal area $6.3\left(\mathrm{~m}^{2} \mathrm{ha}^{-1}\right)$ Shrub cover $20.03 \%$; grass cover $51 \%$ and crown cover of $4 \%$. They are confined mostly to the edges of the reserve, road sides and around the encroaching settlements. Common tree species include Mangifera indica, Adansonia digitata, Parkia bigloboza, Vitaleria paradoxa, and Elaeis guineensis.

\section{Discussion}

The observed differences in the structural composition of the vegetation communities may be attributed to the effect of the magnitude of land use practices that affected the various vegetation communities. Hence, the more the disturbance due to land use practices, the more the trees are likely to vary in height, species density and diversity; as some trees will be more affected than others depending on the purpose for which such trees are needed. This was evidenced by occurrence of young growing trees interspersed with old surviving ones in degraded forest, scrubland, and grassland communities. Another reason for the observed variation in tree height could be explained in terms of natural growth characteristics of different tree species; particularly in the Savannah woodland and Riparian forest that seem to be less affected by anthropogenic interference in such parts 
of the study area. Goudie (1984) and FAO, (1991) confirmed that the factors of plant diversity, complexity and close nutrient cycle that sustain the tropical forest ecosystems in an undisturbed setting makes it fragile when exposed to anthropogenic disturbance.

A comparative analysis of the vegetation structural attributes of the woodland community in the study area with other ecologically similar parts of the world revealed that tree Girth (diameter at breast height) recorded in the study area (0.54- 1.16 metre) is higher than records from miombo woodland Tanzania ranging $4.5-65 \mathrm{~cm}$ (Malimbwi and Temu 1984, Isango 2004). The Simpson's diversity index recorded in the study area is comparably higher than that recorded in the miombo woodland (1-2.85) (Tuite, 1992; Isango, 2004; Malimbwi et al., 1998). The trend of decreasing diversity and density with increasing Girth class was in conformity with the studies of (Hara et al., 1997; Jeffre \& Veillon, 1990; Kadavul \& Parthasarathy, 1999). The tree stand density seem to be lower than that of miombo woodlands which varied between 700-1038 stems/ha (Isango 2004; Backeus et al., 2006). The basal area varied between $6.3-26.9 \mathrm{~m}^{2} /$ ha which is higher than the range (8-16.7 $\mathrm{m}^{2} / \mathrm{ha}$ ) of other studies in Tanzania (Boaler \& Sciwale, 1966, Backeus et al., 2006). Canopy cover in the study area $(4.75-67.73 \%)$ is almost the same as $20-75 \%$ obtainable in Tanzania miombo woodland (Boaler, 1966). Tree height in the study area (11.3-26.6 metre) can also be compared to that of the miombo woodland with value range of 15-30 meter. Therefore the vegetation of the study area have common structural attributes relative to other areas of ecologically similar conditions; though not without some peculiarities as highlighted above. This confirms the principle of ecological amplitudes that stresses that whenever areas of equivalent environmental conditions are encountered, essentially the same plant assemblage reappears.

\section{Summary and Conclusion}

The study and analysis of structural composition of the Kpashimi Forest Reserve revealed quantitatively the distinctive structural attributes of the vegetation communities within the study area. It also made it clear that the Riparian forest has comparatively higher mean values of trunk diameter, basal area tree height and crown cover. Savannah woodland records highest density of tree stand and diversity while Degraded forest, Scrubland, Grassland and Bare surface classes are characterised by high mean values of grass cover and shrub cover with ample evidence of disturbance. This study has made it clearer the current status with regards to structural composition of the study area located in the southern guinea savannah area of Nigeria. The study area in a nutshell is characterised by mosaics of plant communities that vary in composition, diversity, heterogeneity, structure and complexity. Further research is hereby recommended to address the dynamics of plant community complexities over decades in order to provide explanations for the observed structural characteristics of vegetation communities.

\section{Acknowledgement}

We are grateful to the following: Mallam M.A. Mohammad, Director, Forestry, Niger State Ministry of Environment and Forestry Resources, Minna; Mallam Shuaibu Koko, the then Area Forest Officer, Kpashimi Forest Reserve, Lapai for providing professional support and guidance for this study. We are also thankful to all people who assisted in the data collection in the study area as well as village forest guard who escorted and showed us the easy way in to the forest. We thank anonymous reviewers for providing suggestions that greatly improved the manuscript.

\section{References}

Areola, O. (1978). Soil and vegetation resources of Nigeria. In Oguntoyinbo et al. (Eds.), A geography of Nigerian development. Heinemann Education Books Nigeria Limited.

Augustine, D. J. (2003). Spatial heterogeneity in the herbaceous layer of a semi-arid savannah ecosystem. Plant Ecology, 167, 319-332. http://dx.doi.org/10.1023/A:1023927512590

Backeus, I., Pettersson, B., \& Ruffo, C. (2006). Tree communities and structural dynamics in miombo (Brachystegia-Julbernadia) woodlands, Tanzania. Forest Ecology and Management, 230, 171-178. http://dx.doi.org/10.1016/j.foreco.2006.04.033

Boaler, S. B., \& Sciwale, K. C. (1966). Ecology of miombo site, Lupa North Forest Reserve, Tanzania, III: Effects on vegetation of local cultivation practices. Journal of Ecology, 54, 577-578. http://dx.doi.org/10.2307/2257803

Boaler, S. B. (1966). Ecology of miombo site, Lupa North Forest Reserve, Tanzania II. Plant communities and seasonal variation in vegetation. Journal of Ecology, 54, 465-479. http://dx.doi.org/10.2307/2257962

Brown, S., \& Gaston, G. (1996). Estimates of biomass density for tropical forests. In J. S. Levine (ed.), Biomass 
burning and global change (pp. 133-139). Cambridge: The MIT Press.

Bucini, G., \& Hanan, N. P. (2007). A continental-scale analysis of tree cover in African savannahs. Global Ecology and Biogeography, 16, 593-605. http://dx.doi.org/10.1111/j.1466-8238.2007.00325.x

Devineau, J. L., Fournier, A., \& Kaloga, B. (1997). Les sols et la végétation de la région de Bondoukui (Ouest burkinabé). ORSTOM, Paris.

Eyre, T. J., Kelly, A. L., \& Neldner, V. J. (2006). Methodology for the establishment and survey of Reference site for Bio conditions. Version 1.4, Environmental Protection Agency, Biodiversity Science Unit, Brisbone.

Food and Agricultural Organization-FAO. (1991). Shifting cultivators: Local Technical Knowledge and natural resources management in the humid tropics. Rome, pp 80-83.

Food and Agricultural Organization - FAO. (2001). Global forest resources assessment. FAO, Rom.

Food and Agricultural Organization - FAO (2001). Global Forest Resources Assessment: 2000 Main Report F.A.O Forestry paper, 140 F.A.O, Rome.

Forest Management Evaluation and Co-ordinating Unit (FORMECU). (1994). World Bank/Government of Nigeria Forestry III project Vol. VI Environmental Assessment, Forest Management Component, kpashimi Forest Reserve, Final Draft.

Frost, P. (1996). The ecology of miombo woodlands (Africa), Jakarta, CIFOR.

Gareth Williams. (1991). Techniques and Fieldwork in Ecology, Collins Educational, Great Britain, pp. 36-47.

Giri, C., Zhu, Z., \& Reed, B. (2005). A comparative analysis of the Global Land Cover 2000 and MODIS land

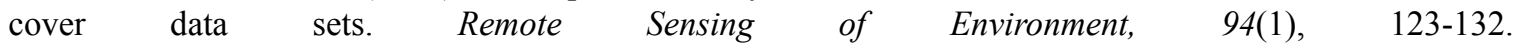
http://dx.doi.org/10.1016/j.rse.2004.09.005

Goudie, A. (1984). The human impact : Man's role in environmental change. Oxford: Blackwell.

Hahn, K. (1996). Die Pflanzengesellschaften der Savannen im Südosten Burkina Fasos (Westafrika). Ihre Beeinflussung durch den Menschen und die Naturräumlichen Gegebenheiten. Dissertation, Universität Frankfurt am Main.

Hansen, M. C., \& Reed, B. (2000). A comparison of the IGBP DISCover and University of Maryland $1 \mathrm{~km}$ global land cover products. International Journal of Remote Sensing, 21(6 \& 7), 1365-1373. http://dx.doi.org/10.1080/014311600210218

Hara, M., Hirata, K., Fujihaxa, M., Oona, K., \& Hsich, C. F. (1997). Floristic composition and stand structure of three evergreen broad-leaved forests in Taiwan, with special reference to the relationship between Micro-landform and vegetation pattern. National Historical Research, 4(Special Issue), 81-112.

Isango, J. A. (2004). Monitoring growth and impact of harvesting options, shifting cultivation and grazing on vegetation growth in miombo woodlands of Iringa District, Tanzania. A collaborative report submitted to MEMA/DANIA Iringa, TAFORI.

Jaiyeoba, I. A., \& Essoka, P. E. (2006). 'Soils and Vegetation' in The Middle Niger River Basin: A field course hand book. Department of Geography, Ahmadu Bello University, Zaria.

Jeffre, T., \& Veillon, J. M. (1990). Etude floristique et structurale de deux forets denses humides surroches ultrabasiques en Nouvelle-Caledonie. Bull. Mus. Hist. Nat. Paris, 12(B), 243-73.

Justice, C., \& Townshend, J. (1981). Integrating Ground data with remote sensing. In J. Townshend (Ed.), Terrain analysis and Remote sensing. London: George Alien and Unwin.

Kadavul, K., \& Parthsarathy, N. (1999). Plant biodiversity and conservation of tropical Semi-evergreen forest in the Shervarayan hills of Eastern ghats, India. Bio-diversity and conservation, 8, 421-439. http://dx.doi.org/10.1023/A:1008899824399

Keay, R.W. J. (1953). An outline of Nigerian Vegetation (2nd ed.). Lagos: Government Printed.

Levick, S. R., Asner, G. P., Kennedy-Bowdoin, T., \& Knapp, D. E. (2009). The relative influence of fire and herbivory on savannah three dimensional vegetation structure. Biological Conservation, 142, 1693-1700. http://dx.doi.org/10.1016/j.biocon.2009.03.004

Loveland, T. R., Zhu, Z., Ohlen, D. O., Brown, J. F., Reed, B. C., \& Yang, L. (1999). An analysis of the IGBP global land-cover characterization process. Phtogrammetric Engineering and Remote Sensing, 65, 1021-1032. 
Malimbwi, R. E., \& Temu, A. B. (1984). Volume functions for P. angolensis and J. globiflora. Journal of Tanzania Association Forestry, 5(1), 49-53.

Malimbwi, R. E., Kielland-Lund, J., \& Nduwanungu, J. (1998). Species diversity and standing crop development in four miombo vegetation communities. Faculty of forestry, Sokoine University of Agricuture, Morogoro. Tanzania.

Martin, G. J. (1996). Ethnobotany: A method manual. Botanic Garden, Kew. UK: Chapman and Hall press.

McNaughton, S. J. (1983). Serengeti grassland ecology: The role of composite environmental factors and contingency in community organization. Ecological Monographs, 53, 291-320. http://dx.doi.org/10.2307/1942533

William, K. M., Thomas, J. B., Penelope, F., Margaret, A. P., James, L. R., Elizabeth, A. S., \& Herman, Z. (2001). Defining and Unraveling Biocomplexity. BioScience, 51(12), 1018-1023. http://dx.doi.org/10.1641/0006-3568(2001)051[1018:DAUB]2.0.CO;2

Ojo, O. (1977). The climates of West Africa. London: Heinemann.

Privette, J. L., Tian, Y., Roberts, G., \& Scholes, R. J., (2004). Vegetation structure characteristics and relationships of Kalahari woodlands and savannahs. Global Change Biology, 10, 281-291. http://dx.doi.org/10.1111/j.1365-2486.2004.00740.x

Ratter, J. A., Ribeiro, J. F., \& Bridgewater, S. (1997). The Brazilian cerrado vegetation and threats to its biodiversity. Annals of Botany, 80, 223-230. http://dx.doi.org/10.1006/anbo.1997.0469

Rosenfield, G. H., Fitzpatrick, L. K., \& King, H. S. (1982). Sampling for Thematic map accuracy testing' in Photogrammetry. Engineering and Remote Sensing, 18, 131-137.

Sanford, W. W., \& Isichei, A. O. (1986). Savannah. In G. W. Lawson (ed.), Plant ecology in West Africa: systems and processes (pp. 95-150). Chichester: John Wiley \& Sons.

Sankaran, M., Hanan, N. P., Scholes, R. J., \& Ratnam, J. (2005). Determinants of woody cover in African savannahs. Nature, 438(7069), 846-9. http://dx.doi.org/10.1038/nature04070

Sarmiento, G. (1984). The ecology of neotropical savannahs. Cambridge: Harvard University Press.

Schmidt, W. (1973). Vegetationskundliche Untersuchungen im Savannenreservat Lamto (Elfenbeinküste). Vegetatio, 28, 145-200. http://dx.doi.org/10.1007/BF02389617

Scholes, R. J., \& Walker, B. H. (1993). An African savannah: Synthesis of the Nylsvley study. Cambridge: Cambridge University Press. http://dx.doi.org/10.1017/CBO9780511565472

Scholes, R. J., Dowty, R. P., Caylor, K., \& Parsons, D. A. B (2002). Trends in savannahh structure and composition along an aridity gradient in the Kalahari. Journal of Vegetation Science, 13, 419-428. http://dx.doi.org/10.1111/j.1654-1103.2002.tb02066.x

Simpson, E. H. (1949). Measurement of Diversity Nature London.

Sinsin, B. (1993). Phytosociologie, écologie, valeur pastorale, production et capacité de charge des pâturages naturels du périmètre Nikki-Kalalé au Nord-Bénin. Dissertation, Université Libre de Bruxelles.

Sokpon, N., Sinadouwirou, T., Gbaguidi, F., \& Biaou, S. H. (2001). Survey of the wetland forests of Benin. Belgian Journal of Botany, 134, 79-93.

Tuite, P. (1992). The ecological status of miombo woodlands in Southern Tanzania. Ph.D. thesis. University College Dublin.

Venter, F. J., Scholes, R. J., \& Eckhardt, H. C. (2003). The abiotic template and its associated vegetation pattern. In J. du Toit, K. Rogers, \& H. Biggs (Eds.), The Kruger experience: Ecology and management of savannah heterogeneity (pp. 83-129). Washington, D.C.: Island Press.

Wratten, S. D., \& Fry, G. L. A. (1980). Field Laboratory Techniques in Ecology. London: Edward Arnold. 


\section{Appendix A}

Location of sample points by their co-ordinates

\begin{tabular}{|c|c|c|c|c|}
\hline S/No. of Points & Vegetation Class & Class Points & Latitude & Longitude \\
\hline 1 & Bare Surface & 1 & $8^{\circ} 48^{\prime} 25.61$ 'N & $6^{\circ} 37^{\prime} 39.77^{\prime \prime} \mathrm{E}$ \\
\hline 2 & & 2 & $8^{\circ} 46^{\prime} 00.67^{\prime \prime} \mathrm{N}$ & $6^{\circ} 37^{\prime} 29.90$ "'E \\
\hline 3 & & 3 & $8^{\circ} 43^{\prime} 27.29^{\prime \prime} \mathrm{N}$ & $6^{\circ} 36^{\prime} 06.86^{\prime \prime} \mathrm{E}$ \\
\hline 4 & & 4 & $8^{\circ} 42^{\prime} 48.70 ” \mathrm{~N}$ & $6^{\circ} 35^{\prime} 49.01^{\prime \prime} \mathrm{E}$ \\
\hline 5 & & 5 & $8^{\circ} 42^{\prime} 11.77^{\prime} \mathrm{N}$ & $6^{\circ} 35^{\prime} 38.52^{\prime \prime} \mathrm{E}$ \\
\hline 6 & & 6 & $8^{\circ} 40^{\prime} 42.66 ” \mathrm{~N}$ & $6^{\circ} 37^{\prime} 02.96$ ” E \\
\hline 7 & & 7 & $8^{\circ} 44^{\prime} 38.92 ” \mathrm{~N}$ & $6^{\circ} 44^{\prime} 53.81$ 'E \\
\hline 8 & & 8 & $8^{\circ} 41^{\prime} 27.88^{\prime \prime} \mathrm{N}$ & $6^{\circ} 41^{\prime} 13.19$ '” \\
\hline 9 & Grass Land & 1 & $8^{\circ} 49^{\prime} 22.00 ” \mathrm{~N}$ & $6^{\circ} 42^{\prime} 12.61$ '” \\
\hline 10 & & 2 & $8^{\circ} 50^{\prime} 42.01 ” \mathrm{~N}$ & $6^{\circ} 39^{\prime} 12.38^{\prime \prime} \mathrm{E}$ \\
\hline 11 & & 3 & $8^{\circ} 50^{\prime} 12.00^{\prime \prime} \mathrm{N}$ & $6^{\circ} 36^{\prime} 46.97^{\prime \prime} \mathrm{E}$ \\
\hline 12 & & 4 & $8^{\circ} 48^{\prime} 19.41 ” \mathrm{~N}$ & $6^{\circ} 37^{\prime} 47.41^{\prime \prime} \mathrm{E}$ \\
\hline 13 & & 5 & $8^{\circ} 41^{\prime} 13.06 ” \mathrm{~N}$ & $6^{\circ} 37^{\prime} 47.01$ '” \\
\hline 14 & & 6 & $8^{\circ} 42^{\prime} 09.49 ” \mathrm{~N}$ & $6^{\circ} 36^{\prime} 59.64$ 'Е \\
\hline 15 & & 7 & $8^{\circ} 44^{\prime} 37.65^{\prime \prime} \mathrm{N}$ & $6^{\circ} 44^{\prime} 58.02$ 'Е \\
\hline 16 & & 8 & $8^{\circ} 45^{\prime} 49.79 ” \mathrm{~N}$ & $6^{\circ} 43^{\prime} 44.95^{\prime \prime} \mathrm{E}$ \\
\hline 17 & Scrubland & 1 & $8^{\circ} 50^{\prime} 56.58^{\prime \prime} \mathrm{N}$ & $6^{\circ} 38^{\prime} 58.16^{\prime \prime} \mathrm{E}$ \\
\hline 18 & & 2 & $8^{\circ} 50^{\prime} 25.40^{\prime \prime} \mathrm{N}$ & $6^{\circ} 37^{\prime} 28.16^{\prime \prime} \mathrm{E}$ \\
\hline 19 & & 3 & $8^{\circ} 46^{\prime} 55.40^{\prime} \mathrm{N}$ & $6^{\circ} 37^{\prime} 07.35^{\prime \prime} \mathrm{E}$ \\
\hline 20 & & 4 & $8^{\circ} 50^{\prime} 24.24 ” \mathrm{~N}$ & $6^{\circ} 41^{\prime} 59.41^{\prime \prime} \mathrm{E}$ \\
\hline 21 & & 5 & $8^{\circ} 42^{\prime} 08.99 ” \mathrm{~N}$ & $6^{\circ} 35^{\prime} 52.18^{\prime \prime} \mathrm{E}$ \\
\hline 22 & & 6 & $8^{\circ} 40^{\prime} 48.78^{\prime \prime} \mathrm{N}$ & $6^{\circ} 39^{\prime} 02.14$ '” \\
\hline 23 & & 7 & $8^{\circ} 41^{\prime} 45.89$ ”N & $6^{\circ} 41^{\prime} 45.10^{\prime \prime} \mathrm{E}$ \\
\hline 24 & & 8 & $8^{\circ} 44^{\prime} 55.41^{\prime \prime} \mathrm{N}$ & $6^{\circ} 45^{\prime} 19.15^{\prime \prime} \mathrm{E}$ \\
\hline 25 & Degraded Forest & 1 & $8^{\circ} 50^{\prime} 36.10^{\prime \prime} \mathrm{N}$ & $6^{\circ} 38^{\prime} 51.17$ 'E \\
\hline 26 & & 2 & $8^{\circ} 49^{\prime} 22.37^{\prime \prime} \mathrm{N}$ & $6^{\circ} 37^{\prime} 08.10^{\prime \prime} \mathrm{E}$ \\
\hline 27 & & 3 & $8^{\circ} 41^{\prime} 30.39 ” \mathrm{~N}$ & $6^{\circ} 36^{\prime} 02.59$ '” \\
\hline 28 & & 4 & $8^{\circ} 42^{\prime} 56.25^{\prime \prime} \mathrm{N}$ & $6^{\circ} 40^{\prime} 21.37^{\prime \prime} \mathrm{E}$ \\
\hline 29 & & 5 & $8^{\circ} 44^{\prime} 16.04^{\prime \prime} \mathrm{N}$ & $6^{\circ} 43^{\prime} 39.43^{\prime \prime} \mathrm{E}$ \\
\hline 30 & & 6 & $8^{\circ} 43^{\prime} 35.13^{\prime \prime N}$ & $6^{\circ} 45^{\prime} 10.96$ ” E \\
\hline 31 & & 7 & $8^{\circ} 46^{\prime} 47.16^{\prime \prime} \mathrm{N}$ & $6^{\circ} 45^{\prime} 05.76^{\prime \prime} \mathrm{E}$ \\
\hline 32 & & 8 & $8^{\circ} 49^{\prime} 24.09 ” \mathrm{~N}$ & $6^{\circ} 43^{\prime} 20.46^{\prime \prime} \mathrm{E}$ \\
\hline 33 & Savanna Woodland & 1 & $8^{\circ} 45^{\prime} 53.79 ” \mathrm{~N}$ & $6^{\circ} 38^{\prime} 22.01$ '” $\mathrm{E}$ \\
\hline 34 & & 2 & $8^{\circ} 43^{\prime} 17.43^{\prime \prime} \mathrm{N}$ & $6^{\circ} 37^{\prime} 30.88^{\prime \prime} \mathrm{E}$ \\
\hline 35 & & 3 & $8^{\circ} 44^{\prime} 19.84 ” \mathrm{~N}$ & $6^{\circ} 40^{\prime} 57.40^{\prime \prime} \mathrm{E}$ \\
\hline 36 & & 4 & $8^{\circ} 42^{\prime} 57.43^{\prime \prime} \mathrm{N}$ & $6^{\circ} 41^{\prime} 25.40^{\prime \prime} \mathrm{E}$ \\
\hline 37 & & 5 & $8^{\circ} 45^{\prime} 58.16 ” \mathrm{~N}$ & $6^{\circ} 41^{\prime} 41.77^{\prime \prime} \mathrm{E}$ \\
\hline 38 & & 6 & $8^{\circ} 47^{\prime} 32.64 ” \mathrm{~N}$ & $6^{\circ} 40^{\prime} 49.79$ '” \\
\hline 39 & & 7 & $8^{\circ} 47^{\prime} 52.89 ” \mathrm{~N}$ & $6^{\circ} 42^{\prime} 52.42^{\prime \prime} \mathrm{E}$ \\
\hline 40 & & 8 & $8^{\circ} 48^{\prime} 12.28^{\prime \prime} \mathrm{N}$ & $6^{\circ} 44^{\prime} 28.43$ ”E \\
\hline 41 & Riparian Forest & 1 & $8^{\circ} 47^{\prime} 26.44^{\prime \prime} \mathrm{N}$ & $6^{\circ} 37^{\prime} 40.59$ ” $\mathrm{E}$ \\
\hline 42 & & 2 & $8^{\circ} 46^{\prime} 48.40^{\prime \prime} \mathrm{N}$ & $6^{\circ} 37^{\prime} 25.11^{\prime \prime} \mathrm{E}$ \\
\hline 43 & & 3 & $8^{\circ} 45^{\prime} 12.61 ” \mathrm{~N}$ & $6^{\circ} 36^{\prime} 43.22^{\prime \prime} \mathrm{E}$ \\
\hline 44 & & 4 & $8^{\circ} 43^{\prime} 19.07^{\prime \prime} \mathrm{N}$ & $6^{\circ} 36^{\prime} 23.96^{\prime \prime} \mathrm{E}$ \\
\hline 45 & & 5 & $8^{\circ} 42^{\prime} 04.13^{\prime \prime} \mathrm{N}$ & $6^{\circ} 41^{\prime} 48.71$ 'Е \\
\hline 46 & & 6 & $8^{\circ} 45^{\prime} 10.58^{\prime \prime} \mathrm{N}$ & $6^{\circ} 44^{\prime} 59.59$ 'Е \\
\hline 47 & & 7 & $8^{\circ} 46^{\prime} 10.28^{\prime \prime} \mathrm{N}$ & $6^{\circ} 42^{\prime} 58.48^{\prime \prime} \mathrm{E}$ \\
\hline 48 & & 8 & $8^{\circ} 48^{\prime} 45.07^{\prime \prime} \mathrm{N}$ & $6^{\circ} 42^{\prime} 55.01$ ' $\mathrm{E}$ \\
\hline
\end{tabular}

\section{Copyrights}

Copyright for this article is retained by the author(s), with first publication rights granted to the journal.

This is an open-access article distributed under the terms and conditions of the Creative Commons Attribution license (http://creativecommons.org/licenses/by/3.0/). 